\title{
The influence of student ethnicity on teacher expectations and teacher perceptions of warmth and competence
}

\author{
Raisa Akifyeva ${ }^{a, b^{*}}$ and Alisa Alieva ${ }^{c}$ \\ a Department of Sociology, National Research University Higher School of Economics, St. Peters- \\ burg, Russia \\ ${ }^{b}$ School of Social Sciences, University of Western Australia, Perth, Australia \\ ' International Centre for Health Economics, Management, and Policy, National Research Uni- \\ versity Higher School of Economics, St. Petersburg, Russia
}

*Corresponding author. E-mail: raisa.akifeva@research.uwa.edu.au

Background. Previous research shows that incorrect teacher expectations about students can affect students' academic success. Moreover, students' ethnicity was found to be one of the most influential characteristics affecting teacher expectations, which can be based on ethnic stereotypes. Most studies test this relationship by comparing teacher expectations of multiple ethnic groups; however, we propose here another perspective, assuming that the connection between ethnic stereotypes and expectations may be determined by the content of the stereotypes.

Objective. This study examines the influence of students' ethnicity on teacher expectations and stereotypes, as well as the relationship of teacher expectations and stereotypes toward ethnic minority students, by including the stereotype content model in the analysis.

Design. Thirty-four primary school teachers participated in the experiment in which they analyzed six fictional profiles of students, two of which were experimental. The experimental profiles contained identical information (annual school grade, a teacher testimonial, gender), but differed in names of the students and their parents, and in their migration background. Thus, we manipulated only the information related to ethnicity and migration history of two students.

Results. Teacher expectations about the performance of minority students were always unfavorable compared with expectations about the performance of the majority students, but their expectations about the abilities of minority and majority students, which include teachers' beliefs about students' educational skills, attitudes and motivation, and capacity for school work, were mixed. We also discovered that the teacher expectations were positively related to perceptions of competence and not to perceptions of warmth. However, the minority student was evaluated by teachers as just as warm and competent as the majority. 
Conclusion. This study shows the relevance of the problem of correct expectations of teachers toward students with different ethnic backgrounds. In contrast to the teachers' perceptions of the warmth and competence of students, information about the ethnicity of the child influences their expectations. Meanwhile the teachers' expectations are differently related to the various components of their stereotypes. The results raise a question about the definition and operationalization of teachers' expectations.

Keywords: teacher expectations, stereotypes, stereotype content model, warmth, competence, ethnic minority students.

\section{Introduction}

Teacher perception of students as members of certain groups can contribute to inequality in schools. According to a classic study by R. Rosenthal and L. Jacobson (1968), incorrect expectations on the part of teachers can trigger the "Pygmalion effect," which manifests itself in the fact that the behavior of students seems to be linked with teacher expectations and students begin to perform in the way that teachers expect from them (Brophy \& Good, 1970; Rosenthal \& Jacobson, 1968). Although follow-up studies have shown contradictory results, there is evidence that teachers' expectations and their beliefs about students were in some cases related to the students' academic success (Ferguson, 2003; Jussim \& Harber, 2005; Peterson, Rubie-Davies, Osborne, \& Sibley, 2016; Rubie-Davies, Hattie, \& Hamilton, 2006).

Furthermore, researchers have been able to identify a number of student characteristics that can influence teacher perceptions, such as gender, socioeconomic status, and special educational needs (Auwarter \& Aruguete, 2008; Levins, Bornholt, \& Lennon, 2005; Page \& Rosenthal, 1990; Ready \& Wright, 2011).

The relationship between student ethnicity and teacher expectations is of particular interest for the study of inter-ethnic relations in the school and the causes of an ethnic achievement gap. Many studies have shown that teacher perceptions may result in ethnic minority students having lower academic achievement than their peers belonging to the ethnic majority (Peterson et al., 2016; Rubie-Davies et al., 2006; Tenenbaum \& Ruck, 2007). One of the most common explanations for the low expectations of teachers toward ethnic minority students is that teachers' perceptions and expectations can be based on ethnic stereotypes (Glock, KrolakSchwerdt, Klapproth, \& Böhmer, 2013; Glock, Krolak-Schwerdt, \& Pit-ten Cate, 2015; Parks \& Kennedy, 2007). This conclusion is not observed in relation to all ethnic minorities, however, or has weak evidence or is not supported at all (Jussim \& Eccles, 1995; Rubie-Davies et al., 2006).

In many studies, the connection between ethnic stereotypes and expectations is tested through the study of the expectations of teachers towards various ethnic minorities. Differences in expectations suggest the influence of a stereotype. It can be assumed that a connection between ethnic stereotypes and expectations is determined by the content of the stereotypes. According to the stereotype content model, each stereotype has two dimensions, "warmth" and "competence", and stereotypes are typically mixed, which means that out-groups may be seen as competent but not warm, or vice versa (Fiske, 2015; Fiske, Cuddy, Glick, \& Xu, 2002). Various dimensions of stereotype may be differently related to academic expectations. It can be assumed that the perception of student "competence" is consistent 
with high expectations on the part of teachers, but student "warmth" is not at all related to the expectations of the teachers towards these students. Thus, the question arises how teacher expectations are related to each of the components of their stereotypes.

While in Western countries the low academic achievement of children belonging to ethnic minorities is a problem that has been studied for decades, the influx of migrants from the CIS countries to Russia, which since the 1990s has resulted in an increasing number of immigrant children in Russian schools, actualizes the problem of correct teacher expectations in a new way in the Russian context. Most of today's immigrants, who bring with them children of all ages, are from Central Asia (Alexandrov, Ivaniushina, \& Kazartseva, 2015). Although xenophobic sentiments in Russia in relation to migrants from countries in this region have been falling in recent years, they are still high: $29 \%$ of Russians surveyed in 2015 believed that immigration from the former Central Asian Soviet republics should be limited and, in $2014,17 \%$ and $20 \%$ of respondents felt anger and hostility towards the migrants from the southern republics, respectively (Levada Center, 2014, 2015). The stereotypical image of migrants is negative: that they are low-skilled and impolite, have a repulsive appearance, have difficulty communicating, and so on (Levada Center, 2013). This data suggests that the stereotypes toward adult migrants would be "contemptuous" or "paternalistic"; that is, that their perceived "competence" is low. Apparently, it is also typical of teachers to perceive "one and a half generation" and first-generation immigrant students as incompetent, because of their real difficulties with the Russian language, which is not their native one, as well as the perception of them as children in need of adaptation to the new environment (Akifyeva, 2015; Alexandrov, Ivaniushina, Kostenko, Savelyeva, \& Tenisheva, 2012). In the present study, we have also tested the hypothesis that teachers perceive immigrant students from Central Asia more paternalistically or contemptuously and have lower expectations for them compared to non-migrant students, which would be correlated with a perception of their low "competence".

Thus, the main question of our research is how a student's ethnicity influences stereotypes and teacher expectations, and how teacher expectations relate to the various components of their stereotypes.

\section{Theoretical Background}

\section{Content of Stereotypes}

Stereotypes can be defined as "qualities perceived to be associated with particular groups and categories of people" (Schneider, 2004, p. 24).

According to the stereotype content model, stereotypes about any social groups are captured by two dimensions: "warmth" and "competence" (Fiske, 2015; Fiske et al., 2002). "Warmth" refers to personal qualities reflecting the positive orientation of members of the perceived group to others (tolerant, warm, good natured, sincere), while "competence" refers to their qualities contributing to success and their abilities (competent, confident, independent, competitive, intelligent). Those researchers showed that the majority of stereotypes in relation to different social groups are mixed, that is, the social group may have a high indicator of one of these 
two scales and a low one on the other (Fiske et al., 2002). This differentiation is the basis for the allocation of two types of ambivalent stereotypes: paternalistic stereotypes, combining high levels of warmth and low levels of competence; and envious stereotypes, combining low levels of warmth and high levels of competence.

This model regarding the content of stereotypes, based on two main dimensions, was confirmed in a study of women and men, different subgroups of women and men (for example, hippy, housewife, yuppie, rocker), and different ethnic groups (Cuadrado-Guirado \& López-Turrillo, 2014; Ebert, Steffens, \& Kroth, 2014; Eckes, 2002; Janssens, Verkuyten, \& Khan, 2015). Research on stereotypes about immigrants demonstrated not only cross-cultural differences in the content of stereotypes, but also differences in relation to the various immigrant groups, for example, in the U.S., "undocumented immigrants" are perceived as having low competence, and "Asians" as having high competence, which correlates with their perceived socioeconomic status (Cuddy et al., 2009; Lee \& Fiske, 2006).

\section{Teacher Expectations and Stereotypes/Attitudes}

According to the definition of Christine Rubie-Davies, "teacher expectations are notions teachers hold about students' long- and short-term performance - beliefs teachers hold about what students are capable of achieving on a daily and longterm basis" (Rubie-Davies, 2008, p. 254).

Starting with the work of Rosenthal and Jacobson (1968), it became clear that there is a deep connection between teacher expectations and student performance (McKown \& Weinstein, 2008; Peterson et al., 2016; Rubie-Davies et al., 2006; van den Bergh, Denessen, Hornstra, Voeten, \& Holland, 2010). Teachers' expectations often unconsciously influence their interaction with students; they display different behavior, provide students with different opportunities to prove themselves in the classroom, praise and encourage some children and offer them additional instructional material (Good, 1987). Low expectations on the part of teachers can result in a child passing an exam with worse results than his real abilities would suggest, and, on the other hand, high teacher expectations can have a positive effect on student motivation and educational aspirations (Brind, Harper, \& Moore, 2008).

Several studies have demonstrated that the perception of students by teachers corresponds to reality; for example, that these are more consistent with the personal characteristics of individual students than with their group characteristics (Jussim \& Eccles, 1995; Madon et al., 1998).

However, many studies have shown that the different group characteristics of students can influence the expectations of teachers. The most studied characteristics, along with gender and socioeconomic status, are ethnicity and migratory status. Many studies suggest that teachers may perceive students belonging to ethnic minorities differently than students who belong to the ethnic majority. However, despite the large number of studies, there is still controversy regarding the nature of this influence. Thus, on the one hand, there is evidence that teachers tend to generate higher expectations for the ethnic minority than for the ethnic majority students (Hachfeld, Anders, Schroeder, Stanat, \& Kunter, 2010). On the other hand, numerous studies have shown that teachers tend to have low expectations for ethnic minority students and to recommend for them a lower educational track 
(Glock et al., 2013; Ready \& Wright, 2011; Rubie-Davies et al., 2006; Tenenbaum \& Ruck, 2007; Wigfield, Galper, Denton, \& Seefeldt, 1999). There are studies in which the results are mixed. For example, depending on the information that is manipulated by the researchers, in some cases minority students were recommended for a higher school track, and in other cases for a lower one than the majority students (Glock et al., 2015). Another study showed that teachers have both favorable and unfavorable expectations of their minority students, depending on how expectations are measured (King Lewis, 2014).

Several authors have studied how expectations of teachers are interconnected with their ethnic stereotypes. A study of the attitudes and expectations of teachers in Germany showed that German teachers have less positive attitudes towards Turkish people than towards Germans, but the attitudes of the teachers are not related to their expectations for German and Turkish students (Sprietsma, 2013). In another study, it was shown that there is a relationship between the implicit attitudes of teachers and their expectations. Teachers who showed negative implicit prejudiced attitudes towards ethnic minorities had expressed low expectations of them (van den Bergh et al., 2010).

Interviews with teachers have confirmed the existence of stereotypes: that their expectations are based on their beliefs about minority students' lack of motivation and their parents' failure to provide them with resources (Turner, Rubie-Davies, \& Webber, 2015). Ethnic stereotypes can mean that teachers and pre-service teachers, after familiarizing themselves with student profiles, ignore real information about minority students, such as their academic grades, and have inaccurate expectations of them (Glock et al., 2015).

Although many researchers have been interested in studying the relationship between stereotypes and expectations, there has been no research examining the relationship between expectations and the content of stereotypes, based on the two dimensions of "warmth" and "competence", even if some of the results can be interpreted in terms of the stereotype content model. For instance, within the studies of expectations and teacher attitudes towards students from different ethnic groups, attitudes were measured by a "feeling thermometer", which has a scale from 0 (very cold/ uncomfortable) to 100 (very warm/ comfortable) (Sprietsma 2013; van Ewijk, 2011). It has been shown that teachers give children from ethnic minorities a lower "temperature" than the ethnic majority. This thermometer directly refers to the measurement of "warmth" from the stereotype content model, but "competence" was not measured in either of these studies.

"Expectations" have been defined and operationalized in a way that may interfere with the researcher's operationalization of a stereotype (Brault et al., 2014; King Lewis, 2014; Regalla, 2013; van den Bergh et al., 2010). For example, van den Bergh et al. constructed a scale measuring teacher expectations according to the definition given by Dusek and Joseph (1983): "teacher perceptions of an individual student's performance, ability, and level of educational attainment" (van den Bergh et al., 2010, p. 507). The scale includes items that measure not only teacher perceptions of the academic success of students in the present and future, such as, "He or she will probably have a successful school career", but also items measuring their perception of the students' abilities, for example, "He or she is an intelligent student", which is a direct reference to the classic scales measuring "competence". 
In summary, while some research has concluded that teacher expectations are based on ethnic stereotypes, studies that have focused on stereotype content indicate that stereotypes of ethnic minorities are typically ambivalent. We believe that taking into consideration the heterogeneity of the content of stereotypes allows a better understanding of the contradictory findings. We assume that it is not the negative image of a group as a whole that affects the expectations of teachers, but only their perceptions of the competence of the members of the group, that is, if teacher expectations are based on a stereotype, then it is the dimension of "competence" that has the most influence, not that of "warmth".

\section{Methods}

Our study involved 34 primary school teachers from five general education schools located in the same district of St. Petersburg. All teachers were women, whose average age was $38.29(\mathrm{SD}=10.22)$, and the average teaching experience was 14.24 years $(\mathrm{SD}=9.74)$.

The experiment was conducted in the Spring of 2015. Teachers were invited to look at the personal profiles of six students and fill in questionnaires that included scales measuring stereotypes and the expectations of the teachers in respect to each student, as well as socio-demographic information about the teachers.

\section{Experimental Design}

Student name is an important marker of ethnicity (Anderson-Clark, Green, \& Henley, 2008), which is most significant for Russian teachers (Panova, 2006). In our study, we operationalized ethnicity through the migration status of the students, as well as their and their parents' ethnic name.

Six excerpts from the "personal profiles" of fictional students were used as stimulus material. The students were said to have completed the second grade in 2014 and then changed schools. Each excerpt looked like a typical Russian school "personal profile" which accompanies students when they start to attend school, leave a school, and throughout their school study. In our research it included: 1) information about the name, gender, date of birth, names of parents, kindergarten address, and former place of study, if there was one; 2) grades which the student received at the end of second grade; and 3) a testimonial prepared by the class teacher after second grade. All of this information is obligatory and has to be included in their personal profiles if a student changes school in Russia.

Only two of the six personal profiles were experimental. These contained identical information (school grade, testimonial, gender - male; date of birth - October 15, 2007), but the two children were given different names (Ilya Barabanov was used as ethnically neutral and Ahmad Sangaliev as ethnically marked), and similarly for the names of their parents. Both students had a migrant background, but Ilya had moved to St. Petersburg from Moscow, and Ahmad had moved from Tashkent, Uzbekistan. This migration experience was reflected in the section that contained information about where they had studied in the past and the address of that school (one in Moscow and one in Tashkent). Thus, in the course of the experiment, we manipulated only information related to ethnicity and migration history: the names of the children and parents and the fact of moving from another 
capital city. This allowed us to create a typical image of a "one and a half generation" migrant child, who had moved to St. Petersburg from Central Asia. In this article, the student with external migration history (Ahmad) will be called the ethnic minority student, and the student with internal migration history the ethnic majority student.

During the experiment, the teacher filled in two types of questionnaires: one with questions about expectations and stereotypes in relation to the students, and another which collected socio-demographic data about teachers, as well as a rating expectation scale.

\section{Measures}

Stereotypes. These were measured by eight classic scales used in the study of the content of stereotypes: four focused on the measurement of "warmth" (good natured, friendly, sincere, warm) and four on the measurement of "competence" (capable, intelligent, efficient, confident) (Fiske, 2002). To avoid bias in the estimation, some adjectives were replaced by semantic opposites: warmth (good natured, unfriendly, insincere, cold) and competence (capable, intelligent, efficient, unconfident). Respondents were asked to rate on a five-point Likert scale (where 1 - "totally disagree" and 5 - "totally agree"), "... the extent to which each of the following qualities corresponds to the student ...", whose personal profiles they had read. Scale antonyms were recoded during data analysis, so for clarity, we will continue to call them "friendly", "sincere", "warm", "confident".

Expectations. These were measured in several ways:

1) using eight scales which were made by short adaptation of Regalla's scales (Regalla, 2013), each of which represents a degree of agreement (from 1 "totally disagree" to 5 - "totally agree") with the items about student performance in the present and the future, and his/her academic potential:

1. In your opinion, at the new school this student will perform academically as well as his middle-class peers.

2. In your opinion, at the new school this student is capable of at least average academic performance in all subjects.

3. In your opinion, at the new school this student is capable of learning the material presented in class.

4. In your opinion, at the new school this student has the skills necessary to be successful in school.

5. In your opinion, at the new school this student is motivated to do his best in class.

6. In your opinion, at the new school this student works very hard to do his best in class.

7. In your opinion, at the new school this student will quit school in high school.

8. In your opinion, at the new school this student thinks that education is very important.

During data analysis, the item "In your opinion, at the new school this student will quit school in high school" was recoded so that all items were about positive expectations. Therefore, we call this item "will not quit school in high school". 
All items were translated into Russian by a multiple back-translation procedure applying to all stereotypes and Regalla's scales. Similarly, antonyms for stereotypes were chosen.

2) Using rating scale expectations. Respondents were asked to rate the six children whose "personal profile" they evaluated, in accordance with their expected future academic performance; therefore, the scale ranges from 1 ("will study better than other students") to 6 ("will study worse than other students").

3) Teachers also pointed out how well they thought each of the children would study at the end of the third grade (i.e., one year after the "personal profiles" had been prepared) in four subjects: Russian language, mathematics, English language, and literature. The scales ranged from 1 to 5 , where $1=$ "very badly" and 5 - "very well".

\section{Procedure}

Data was collected from each teacher individually. Teachers were informed that the research focused on the role that information from the personal profiles plays in the educational process. Teachers were asked to familiarize themselves with the first personal profile and form an impression of the child. When the teachers announced their readiness, the "personal profile" was taken away and Questionnaire 1 was issued. Therefore, teachers familiarized themselves with all six profiles and filled in six questionnaires, one for each student. After that, the teacher was given Questionnaire 2 and the experiment ended.

Personal profiles were issued in strict sequence: One of the experimental profiles was always shown second, and the other was always shown sixth. The two experimental profiles were randomly swapped between positions two and six, with some teachers receiving the experimental majority student profile in position two, some in position six, and the same for the minority profile. This was done in order to eliminate the effect of information from the non-experimental personal profiles on perception of the experimental profiles.

A pilot study was conducted to make sure that the teachers did not notice the virtually identical content of the two experimental profiles. Four subjects participated in the entire experiment from beginning to end. None of the subjects during the pilot study noticed that two of the six profiles were identical (except the characteristics that had been manipulated - ethnicity and migration background).

We analyzed the teachers' responses with respect to only the two experimental profiles.

\section{Results}

\section{Perceptions of Ethnic Minority and Majority Students: Differences in Teachers' Stereotypes and Expectations}

In the first stage of the analysis, we created generalized scales measuring teachers' stereotypes and expectations by calculating the arithmetic means of the initial variables. This resulted in 10 scales ( 5 for minority and 5 for majority students): 
1. "Warmth" scale (good natured, friendly, sincere, warm), Cronbach's alpha $=0.68$ for majority student and 0.83 for minority student;

2. "Competence" scale (capable, intelligent, efficient, confident), Cronbach's $\alpha=0.35$ for majority student and 0.71 for minority student;

3. Teacher expectations about performance which included sub-scales measuring teachers' notions about students' performance (prospective grades in 1) mathematics, 2) Russian language, 3) literature, and 3) English language, as well as two Regalla sub-scales 4) "this student will perform academically as well as his middle-class peers", and 5) "the student is capable of at least average academic performance in all subjects"), Cronbach's alpha $=0.39$ for majority student and 0.84 for minority student;

4. Teacher expectations about abilities, including sub-scales measuring teachers' evaluation of student's abilities (the remaining six Regalla scales), Cronbach's alpha $=0.58$ for majority student and 0.69 for minority student;

5. The resulting overall measure of teacher expectations, which combined all expectation sub-scales included in the two expectation variables above; Cronbach's alpha $=0.65$ for majority student and 0.82 for minority student.

While for minority student all Cronbach's alphas could be interpreted as acceptable, low alpha scores for majority student technically indicate unreliable scales. However, low alpha scores for all scales in which the teacher was evaluating of the majority student indicate low internal consistency of the variables, which may reflect the out-group covariation effect supported by the research of Patricia W. Linville, Gregory W. Fischer, and Carolyn Yoon (1996). According to this effect, people tend to perceive greater covariation among the features of out-group members compared with their perception of in-group members. Moreover, low alpha scores for the generalized scales associated with two dimensions of stereotype in the case of the majority student can signify that teachers do not perceive the student in a stereotypical way, whereas in case of the minority student, teachers' stereotypes are activated, and that could be why the stereotype content model finds support in this case. Nevertheless, Cronbach's alpha as a reliability estimate and a measure of internal consistency, has major problems (Field, 2013). For example, the value of alpha depends on the number of items in the scale, and therefore alpha increases as the number of items increases.

Then we studied the differences in teachers' perceptions of the ethnic minority and majority students and expectations about them. Comparative analysis using the paired-samples t-test showed no significant differences in teachers' evaluations of the ethnic minority and majority students on the "warmth" and "competence" scales or the scale that measured expectations about abilities. The null hypothesis can be accepted, that there are no significant differences in the teachers' stereotypical perception of students with different ethnic and immigrant backgrounds on either the warmth or competence scales $(t=0, p=1 ; t=0, p=1)$ (Table 1). On average, teachers held significantly lower expectations about the performance of the minority student $(M=3.45, S E=0.09)$ compared with the majority student $(M=3.85$, $\mathrm{SE}=0.05)$. This difference, 0.41 , BCa $95 \% \mathrm{CI}[0.18,0.63]$, was significant $\mathrm{t}(33)=3.79$, $\mathrm{p}=0.01$ and represents a large effect, $\mathrm{r}=0.55$. There was also a significant difference $(0.22, \mathrm{BCa} 95 \% \mathrm{CI}[0.01,0.43], \mathrm{t}(33)=2.16, \mathrm{p}=0.04)$ in the resulting overall measure 
of teacher expectations in respect to the minority student $(\mathrm{M}=3.38, \mathrm{SE}=0.08) \mathrm{com}$ pared to the majority student $(\mathrm{M}=3.60, \mathrm{SE}=0.05)$, which represented a mediumsized effect, $r=0.35$.

Table 1. Means of the stereotypes and expectations scales, values of $t$, effect sizes, and results of bootstrapping

\begin{tabular}{|c|c|c|c|c|c|}
\hline & $\begin{array}{c}\mathbf{M} \\
\text { Majority } \\
\text { (SE) }\end{array}$ & $\begin{array}{c}\text { M } \\
\text { Minority } \\
\text { (SE) }\end{array}$ & $\mathrm{t}(\mathbf{3 3})$ & $\mathbf{r}$ & BCa 95\% CI \\
\hline warmth & $\begin{array}{c}3.75 \\
(0.09)\end{array}$ & $\begin{array}{c}3.75 \\
(0.10)\end{array}$ & $\begin{array}{c}0 \\
(\mathrm{p}=1.00)\end{array}$ & 0 & {$[-0.18,0.19]$} \\
\hline competence & $\begin{array}{c}3.64 \\
(0.07)\end{array}$ & $\begin{array}{c}3.64 \\
(0.09)\end{array}$ & $\begin{array}{c}0 \\
(\mathrm{p}=1.00)\end{array}$ & 0 & {$[-0.21,0.22]$} \\
\hline expectations about performance & $\begin{array}{c}3.85 \\
(0.05)\end{array}$ & $\begin{array}{c}3.45 \\
(0.09)\end{array}$ & $\begin{array}{c}3.79 \\
(p=0.01)\end{array}$ & 0.55 & {$[0.18,0.63]$} \\
\hline expectations about abilities & $\begin{array}{c}3.34 \\
(0.08)\end{array}$ & $\begin{array}{c}3.32 \\
(0.09)\end{array}$ & $\begin{array}{c}0.21 \\
(\mathrm{p}=0.84)\end{array}$ & 0.04 & {$[-0.21,0.26]$} \\
\hline general expectation scale & $\begin{array}{c}3.60 \\
(0.05)\end{array}$ & $\begin{array}{c}3.38 \\
(0.08)\end{array}$ & $\begin{array}{c}2.16 \\
(\mathrm{p}=0.04)\end{array}$ & 0.35 & {$[0.01,0.43]$} \\
\hline
\end{tabular}

In the next step of the analysis we used the Wilcoxon test to compare the teachers' expectations of the ethnic minority and majority students, measured by the expectation sub-scales. This revealed differences in most cases. Predicting the students' performance at the end of the school year for four subjects (mathematics, Russian language, English language, and literature), the teachers believed that the minority student would perform worse than the majority one (Table 2). The prospective grades of the minority student are significantly lower than those of the majority student, although in the experiment the teachers were shown an identical school progress record, according to which students at the end of the second grade got a grade of 4 for Russian language, literature, and foreign languages, as well as a 5 for mathematics. In the Russian educational system, the following grading scheme is used: 5 (excellent), 4 (good), 3 (satisfactory), 2 (fail).

Table 2. Means of expectation sub-scales (grades), values of $z$, and effect sizes

\begin{tabular}{|c|c|c|c|c|}
\hline & $\begin{array}{c}\mathbf{M} \\
\text { Majority } \\
\text { (SD) }\end{array}$ & $\begin{array}{c}\text { M } \\
\text { Minority } \\
\text { (SD) }\end{array}$ & z & $\mathbf{r}$ \\
\hline $\begin{array}{l}\text { How well he will study mathematics at the } \\
\text { end of the third grade }\end{array}$ & $\begin{array}{c}4.41 \\
(0.56)\end{array}$ & $\begin{array}{c}4 \\
(0.79)\end{array}$ & $\begin{array}{c}-2.56 \\
(\mathrm{p}=0.01)\end{array}$ & -0.31 \\
\hline $\begin{array}{l}\text { How well he will study the Russian language } \\
\text { at the end of the third grade }\end{array}$ & $\begin{array}{l}3.65 \\
(0.49)\end{array}$ & $\begin{array}{c}3.39 \\
(0.52)\end{array}$ & $\begin{array}{c}-2.68 \\
(\mathrm{p}=0.01)\end{array}$ & -0.32 \\
\hline $\begin{array}{l}\text { How well he will study literature at the end } \\
\text { of the third grade }\end{array}$ & $\begin{array}{c}4.00 \\
(0.43)\end{array}$ & $\begin{array}{c}3.56 \\
(0.66)\end{array}$ & $\begin{array}{c}-3.27 \\
(\mathrm{p}=0.00)\end{array}$ & -0.40 \\
\hline $\begin{array}{l}\text { How well he will study the English language } \\
\text { at the end of the third grade }\end{array}$ & $\begin{array}{c}3.79 \\
(0.41)\end{array}$ & $\begin{array}{c}3.44 \\
(0.61)\end{array}$ & $\begin{array}{c}-3.21 \\
(\mathrm{p}=0.00)\end{array}$ & -0.39 \\
\hline
\end{tabular}


Teachers also indicated that those two students in general were different in progress and believed that the «local» student would study significantly better than the «migrant» one:

Those who study better than other students: $(\mathrm{Mdn} 1=3, \mathrm{Mdn} 2=5, \mathrm{z}=-4.66$, $\mathrm{p}=0.00, \mathrm{r}=-0.57)$.

When the teachers ranked the six students whose personal profiles were shown in the experiment, $56 \%$ of the teachers put the majority student at the 1 st-3rd places and $100 \%$ at the 1 st- 4 th places, while $85 \%$ of the teachers put the minority student at 4 th-6th places and $3 \%$ at the 1 st-2nd places. Only 3 teachers out of the 34 believed that the minority student would study better than the majority student; the others suggested the opposite.

The analysis also showed significant differences when comparing the teachers' evaluations of students on four items of the Regalla scales (Table 3). Teachers assessed the student marked as minority significantly lower on three items; however, in one case, we observed the opposite effect: The teachers evaluated the "migrant» significantly higher on the item "works very hard to do their best in class". Statistically significant differences were not found when comparing the evaluations assigned to the rest of the Regalla scales.

Table 3. Means of expectation sub-scales (Regalla), values of $\mathrm{z}$ and effect sizes

\begin{tabular}{lcccc}
\hline & $\begin{array}{c}\mathbf{M} \\
\text { Majority } \\
\text { (SD) }\end{array}$ & $\begin{array}{c}\mathbf{M} \\
\text { Minority } \\
\text { (SD) }\end{array}$ & $\mathbf{z}$ & $\mathbf{r}$ \\
\hline $\begin{array}{l}\text { This student will perform academically as } \\
\text { well as his middle-class peers }\end{array}$ & 3.44 & 2.97 & -2.66 & -0.32 \\
This student is capable of at least average & 3.82 & 3.41 & -2.22 & -0.27 \\
academic performance in all subjects & $(0.63)$ & $(0.82)$ & $(\mathrm{p}=0.04)$ & \\
This student is capable of learning the & 3.79 & 3.41 & -2.20 & -0.27 \\
material presented in class & $(0.59)$ & $(0.89)$ & $(\mathrm{p}=0.03)$ & \\
This student works very hard to do his & 2.85 & 3.18 & -2.01 & -0.24 \\
best in class & $(0.82)$ & $(0.72)$ & $(\mathrm{p}=0.04)$ & \\
This student has the skills necessary to be & 3.53 & 3.38 & -0.93 & -0.11 \\
successful in school & $(0.86)$ & $(0.85)$ & $(\mathrm{p}=0.35)$ & \\
This student is motivated to do his best & 3.15 & 3.32 & -0.98 & -0.12 \\
in class & $(0.89)$ & $(0.81)$ & $(\mathrm{p}=0.33)$ & \\
This student will not quit school in high & 3.65 & 3.44 & -0.94 & -0.11 \\
school & $(0.81)$ & $(1.02)$ & $(\mathrm{p}=0.35)$ & \\
This student thinks that education is very & 3.09 & 3.18 & -0.43 & -0.05 \\
important & $(0.71)$ & $(0.90)$ & $(\mathrm{p}=0.67)$ & \\
\hline
\end{tabular}

These results demonstrate the heterogeneity of teachers' expectations: While no significant differences were found in four sub-scales, on the other four subscales they did exist and demonstrated mixed expectations: For three items of the scale, teacher expectations were higher for the majority student and for one item, expectations were higher for the minority student. Moreover, teachers' expectations about student's performance are underestimated in relation to the ethnic mi- 
nority student compared to the ethnic majority, while expectations about student's abilities are both favorable and unfavorable, which is consistent with other studies of teachers' expectations about minority and majority students (King Lewis, 2014; Regalla, 2013).

\section{Analysis of Relations Between Teachers' Stereotypes and Expectations}

Table 4 shows Spearman's correlation coefficients for all the created scales for majority student. Correlation analysis shows that neither "warmth" nor "competence" is statistically related to the scales measuring teacher expectations about performance, teacher expectations about abilities, and the general expectation scale.

Table 4. Spearman's correlation coefficients for all variables created for the majority student

\begin{tabular}{lccccc}
\hline & $\mathbf{1}$ & $\mathbf{2}$ & $\mathbf{3}$ & $\mathbf{4}$ & $\mathbf{5}$ \\
\hline warmth & 1 & -0.08 & 0.02 & 0.12 & 0.11 \\
competence & & 1 & 0.19 & 0.24 & 0.25 \\
expectations about performance & & & 1 & 0.28 & $0.68^{\star}$ \\
expectations about abilities & & & & 1 & $0.87^{\star}$ \\
general expectations & & & & & 1 \\
\hline
\end{tabular}

${ }^{*} \mathrm{p}=0.00$

The same analysis for the minority student reveals a significant relationship between the "competence" scale and all the expectation scales $(\mathrm{p}=0.00)$. The "warmth" scale is insignificantly related to "competence" $(\mathrm{r}=0.21, \mathrm{p}=0.23)$, "expectations about performance" ( $\mathrm{r}=0.18, \mathrm{p}=0.31)$, "expectations about abilities" ( $\mathrm{r}=0.25, \mathrm{p}=0.16)$, and the general expectations scale $(\mathrm{r}=0.18, \mathrm{p}=0.30)$.

Table 5. Spearman's correlation coefficients for all variables created for the minority student

\begin{tabular}{lccccc}
\hline & $\mathbf{1}$ & $\mathbf{2}$ & $\mathbf{3}$ & $\mathbf{4}$ & $\mathbf{5}$ \\
\hline warmth & 1 & 0.21 & 0.18 & 0.25 & 0.18 \\
competence & & 1 & $0.59^{\star}$ & $0.65^{\star}$ & $0.74^{\star}$ \\
expectations about performance & & & 1 & $0.38^{\star *}$ & $0.86^{\star}$ \\
expectations about abilities & & & & 1 & $0.76^{\star}$ \\
general expectations & & & & & 1 \\
\hline
\end{tabular}

${ }^{*} \mathrm{p}=0.00,{ }^{*} \mathrm{p}=0.03$

The results of the analysis show that teachers' expectations regarding the minority student are not related to their perception of his warmth, but related to the perception of his competence - the more competent the minority student is perceived, the higher are teacher expectations, measured in different ways - beliefs about how well he will study and which abilities are needed for his education. These 
results partially confirm our hypothesis that when studying the relationship between teacher expectations and stereotypes, it is necessary to take into account the content of stereotypes and their homogeneity.

For the next stage of the analysis, stereotypes and expectations sub-scales were recoded. We have created new variables for all sub-scales measuring stereotypes and expectations with 21 new variables. For each pair of variables ("majority student"/ "minority student"), new variables were created, which reflected the differences in the evaluation of minority and majority students by each teacher on each scale. Thus, if a teacher evaluates the majority student higher than the minority one, a value of «1» is assigned to a new variable; if a teacher evaluates the minority student higher than the majority one, the value of the variable is «-1»; and if a teacher evaluates both students equally, it is assigned a value of « 0 ». The variables finally created reflect the stereotypes and expectations of the teachers, their biases. While these scales measure the difference between teachers' expectations of minority and majority students, not the expectations as such, for convenience we use the terms proposed above to identify them. In further analysis, we will use only the new variables.

Then, we created generalized variables from these new variables by calculating their arithmetic means: "warmth" (Cronbach's alpha $=0.65)$, "competence" (Cronbach's alpha $=0.66$ ), teacher expectations about performance (Cronbach's alpha = 0.84 ), teacher expectations about abilities (Cronbach's alpha $=0.64)$, overall measure of teacher expectation (Cronbach's alpha $=0.84$ ).

For the resulting overall measure of teacher expectations and the measure of teacher expectations about performance, the items that were included in these variables were z-scored, because the items' scores have different dimensions. Table 6 shows Spearman's correlation coefficients for all new created scales.

Table 6. Spearman's correlation coefficients for all new created variables

\begin{tabular}{lccccc}
\hline & $\mathbf{1}$ & $\mathbf{2}$ & $\mathbf{3}$ & $\mathbf{4}$ & $\mathbf{5}$ \\
\hline warmth & 1 & 0.11 & 0.00 & 0.02 & 0.02 \\
competence & & 1 & $0.55^{*}$ & $0.66^{*}$ & $0.62^{\star}$ \\
expectations about performance & & & 1 & $0.56^{*}$ & $0.90^{*}$ \\
$\begin{array}{l}\text { expectations about abilities } \\
\text { general expectation scale }\end{array}$ & & & & 1 & $0.83^{*}$ \\
\hline
\end{tabular}

${ }^{*} \mathrm{p}=0.00$

"Competence» is statistically related to all the scales of expectations $(\mathrm{p}=0.00)$. There was no significant relationship between "warmth" and "competence" $(\mathrm{r}=$ $0.11, \mathrm{p}=0.54)$, "warmth" and expectations about abilities $(\mathrm{r}=0.02, \mathrm{p}=0.91)$, "warmth" and the general expectation scale $(\mathrm{r}=0.02, \mathrm{p}=0.91)$. The null hypothesis can be accepted that «warmth» is not related to expectations about performance ( $\mathrm{r}$ $=0.00, p=0.99$ ). The analysis once again confirms our hypothesis about the relationship between the teachers' expectations and the "competence" dimension, but not the "warmth" dimension. 


\section{Discussion}

This study contributes to the debate on the relationship between teachers' expectations and stereotypes in relation to students with different migrant backgrounds, by including the stereotype content model in our analysis.

We examine whether teacher expectations are related differentially to their perceptions of warmth and competence of ethnic minority students. The results confirmed our hypothesis that the expectations of teachers positively related to perceptions of competence and not to perceptions of warmth. This study, in our opinion, provides a new way to answer the question whether expectations are related to stereotypes. We propose to take into consideration the fact that, in accordance with the stereotype content model, stereotypes are more complicated than just being positive or negative: They have a two-dimensional structure and vary according to the perceived warmth and competence of the group (Cuddy et al., 2009; Fiske, 2015; Fiske et al., 2002; Lee \& Fiske, 2006). According to this view, people perceive migrants as competent to a certain degree and warm to a different degree (Lee \& Fiske, 2006). We studied teachers' perceptions of the migrant student from Central Asia as a typical ethnic minority student for St. Petersburg schools. The research would benefit if there had been an opportunity to explore the special features of teachers' perception of not only the migrant student from Central Asia, but also of other migrant groups that are assigned to different clusters, based on warmth and competence scores.

Migrants from Central Asia are a group that has been perceived negatively by Russians for many years. Various opinion surveys have shown that they are perceived as people with low competence (see, for example, Levada Center, 2013). The same trend is observed in relation to migrant children in the context of Russian schools - teachers perceive them as less competent than Russian students (Akifyeva, 2015; Alexandrov et al., 2012). We believe that our research confirms this tendency, but the results have turned out to be more complicated.

Looking at the content of the stereotypes, there are no statistical differences in the evaluation of the minority and the majority students by teachers on the "warmth" and "competence" scales. Since teachers judged equally the two experimental profiles out of the six that were shown, it can be assumed that some of the same information from the profiles had an influence on the teachers' judgments about these children. The testimonials indicated which personal qualities students had, from the point of view of teachers from their previous schools, and it is possible that this was the information on which teachers relied when forming their images of the students. Previous experimental studies have shown that teachers' judgments about ethnic minorities depend on the type of information that the teacher received about the student: expectation-confirming or expectation-disconfirming information (Glock, 2016; Glock \& Krolak-Schwerdt, 2013). It is possible that the results were influenced by what type of information (confirming or disconfirming) was in the testimonials. If the information was disconfirming, evaluations of teachers probably do not reflect stereotypes that they may hold. Following Glock and Krolak-Schwerdt, we can assume that the information on the personal qualities of a student that teachers receive from external sources plays an important role, at least in the formation of their first impression of the student. However, additional 
research is necessary to make sure that it was the information in the testimonials that had an impact on the fact that the teachers evaluated the students equally. Additionally, the small sample size does not allow us to conclude that the differences are not random.

This study showed the relevance of the problem of correct expectations of teachers in relation to students with different ethnic backgrounds, in the context of Russian schools. In contrast to the teacher perceptions of the warmth and competence of students, information about the ethnicity of the child influences their expectations. Teachers' expectations about the performance of minority student were always more unfavorable than expectations about the performance of majority students. Given that we presented to teachers identical records within both profiles, it can be concluded that in forming judgments about the potential performance of children with a migration background, teachers take into account the ethnicity of the children, which is an important factor that determined the significant differences in the forecasts of performance of the students of different ethnicities. These results are consistent with those of the experimental study in which researchers manipulated ethnicity in the profile of students, leaving unchanged other information, including grades, and showed that in-service and pre-service teachers more poorly memorized grades from the profiles of ethnic minority students and, when making school placement recommendations for them, they paid less attention to information about their grades than for ethnic majority students (Glock et al., 2015).

Our study also demonstrated that teacher expectations about the abilities of minority and majority students, which include teacher beliefs about students' educational skills, attitudes and motivation, and capacity for schoolwork, are mixed. The teachers believed that the minority students work harder to do their best in class and are less capable of learning the material presented in class than the majority students. This indicates that the expectations of teachers with regard to the minority students can be both favorable and unfavorable, which confirms the findings of some studies (King Lewis, 2014; Regalla, 2013). These results raise a question about the definition and operationalization of teacher expectations. Teacher expectations are often defined as teacher perceptions of academic success as well as of the abilities of students (Rubie-Davies, 2008; van den Bergh et al., 2010), which is reflected in the operationalization of the phenomenon, in particular through measures that include questions about school achievements and the abilities of students (van den Bergh et al., 2010).

Previous research has mostly focused on teachers' beliefs about students' school achievements (McKown \& Weinstein, 2008; Peterson et al., 2016; RubieDavies, Flint, \& McDonald, 2012; Timmermans, de Boer, \& van der Werf, 2016). Meanwhile, multiple operationalizations of teacher expectations were utilized even in earlier studies (Bognar, 1983; Hoge, 1984; Williams, 1976). Williams proposed a two-factor model of teacher expectations, which included cognitive expectations - "expectations for student performance in academic (instruction) activities" and normative expectations - "expectations for student adherence to the norms of classroom behavior" (Williams, 1976), operationalized as ratings on students' reliability, cooperation, and industry. It has been shown that teachers' cognitive expectations have a positive effect on teachers' normative expectations about female students and a negative effect on teachers' normative expectations about male stu- 
dents. These results indicate that teachers can have a mixture of favorable and unfavorable expectations with respect to students with specific attributions (gender, in this case). Thus, there are studies that indicate that in some cases, expectations may be mixed, but more research is required to explain all the various cases.

\section{Acknowledgments}

We thank Vladimir Volokhonsky for his helpful comments and suggestions and Eduard Ponarin, without whose support this research would not have been conducted. We also thank the teachers for agreeing to participate in this study. As part of the work on the article went within "Fostering Public Health and Quality of Life: Developing and Improving Current Methodology" (2018) research project, Alisa Alieva greatfully acknowledges financial support provided by National Research University Higher School of Economics, St. Petersburg.

\section{References}

Akifyeva, R. (2015). Deti i roditeli v kontekste migratsii: nesoglasovannye traektorii [Children and parents in the migration context: Dissonant or consonant trajectories]. Etnograficeskoe Obozrenie [Ethnographic Review], 5, 117-134.

Alexandrov, D., Ivaniushina, V., \& Kazartseva, E. (2015). Etnicheskiy sostav shkol i migratsionniy status shkol'nikov v Rossii [Ethnic composition and migration status of primary and secondary school students in Russia]. Voprosy obrazovaniya [Educational Studies], 2, 173195. http://doi.org/10.17323/1814-9545-2015-2-173-195

Alexandrov, D., Ivaniushina, V., Kostenko, V., Savelyeva, S., \& Tenisheva K. (2012). Polozhenie detey migrantov v Sankt-Peterburge [Situation with migrant children in Saint Petersburg]. Moscow: United Nations Children's Fund. https://slon.hse.ru/data/2012/08/27/1242919948/ Polozhenie\%20detey\%20migrantov\%20v\%20St.\%20Peterburge\%20(FULL).pdf

Anderson-Clark, T.N., Green, R.J., \& Henley, T.B. (2008). The relationship between first names and teacher expectations for achievement motivation. Journal of Language and Social Psychology, 27(1), 94-99. http://doi.org/10.1177/0261927X07309514

Auwarter, A.E., \& Aruguete, M.S. (2008). Effects of student gender and socioeconomic status on teacher perceptions. Journal of Educational Research, 101(4), 242-246. http://doi. org/10.3200/JOER.101.4.243-246

Bognar, C.J. (1983). Teacher expectations and student characteristics. Canadian Journal of Education, 8(1), 47-56. http://doi.org/10.2307/1494405

Brault, M.-C., Janosz, M., \& Archambault, I. (2014). Effects of school composition and school climate on teacher expectations of students: A multilevel analysis. Teaching and Teacher Education, 44, 148-159. http://doi.org/10.1016/j.tate.2014.08.008

Brind, T., Harper, C., \& Moore, K. (2008). Education for migrant, minority, and marginalised children in Europe, a report commissioned by the Open Society Institute's Education Support Programme. http://citeseerx.ist.psu.edu/viewdoc/download?doi=10.1.1.455.6306\&rep $=$ rep $1 \&$ type $=$ pdf

Brophy, J.E., \& Good, T.L. (1970). Teachers' communication of differential expectations for children's classroom performance: Some behavioral data. Journal of Educational Psychology, 61(5), 365-374. http://doi.org/10.1037/h0029908

Cuadrado-Guirado, I., \& López-Turrillo, E. (2014). What do adolescents think and feel about the different female subtypes? An application of the stereotype content model (SCM). Revista de Psicología Social, 29(2), 235-264. http://doi.org/10.1080/02134748.2014.918823 
Cuddy, A.J.C., Fiske, S.T., Kwan, V.S.Y., Glick, P., Demoulin, S., Leyens, J.-P., ... Ziegler, R. (2009). Stereotype content model across cultures: Towards universal similarities and some differences. British Journal of Social Psychology, 48(1), 1-33. http://doi. org $/ 10.1348 / 014466608 X 314935$

Dusek, J.B., \& Joseph, G. (1983). The bases of teacher expectancies: A meta-analysis. Journal of Educational Psychology, 75(3), 327-346. http://doi.org/10.1037/0022-0663.75.3.327

Ebert, I.D., Steffens, M.C., \& Kroth, A. (2014). Warm, but maybe not so competent?-Contemporary implicit stereotypes of women and men in Germany. Sex Roles, 70(9-10), 359-375. http://doi.org/10.1007/s11199-014-0369-5

Eckes, T. (2002). Paternalistic and envious gender stereotypes: Testing predictions from the stereotype content model. Sex Roles, 47(3), 99-114. http://doi.org/10.1023/A:1021020920715

Ferguson, R. F. (2003). Teachers' perceptions and expectations and the Black-White test score gap. Urban Education, 38(4), 460-507. http://doi.org/10.1177/0042085903254970

Field, A.P. (2013). Discovering statistics using IBM SPSS statistics (4th Edition). SAGE Publications Ltd.

Fiske, S.T. (2015). Intergroup biases: a focus on stereotype content. Current Opinion in Behavioral Sciences, 3, 45-50. http://doi.org/10.1016/j.cobeha.2015.01.010

Fiske, S.T., Cuddy, A. J. C., Glick, P., \& Xu, J. (2002). A model of (often mixed) stereotype content: Competence and warmth respectively follow from perceived status and competition. Journal of Personality and Social Psychology, 82(6), 878-902. http://doi.org/10.1037//00223514.82.6.878

Glock, S. (2016). Does ethnicity matter? The impact of stereotypical expectations on in-service teachers' judgments of students. Social Psychology of Education, 1-17.http://doi.org/10.1007/ s11218-016-9349-7

Glock, S., \& Krolak-Schwerdt, S. (2013). Does nationality matter? The impact of stereotypical expectations on student teachers' judgments. Social Psychology of Education, 16(1), 111-127. http://doi.org/10.1007/s11218-012-9197-z

Glock, S., Krolak-Schwerdt, S., Klapproth, F., \& Böhmer, M. (2013). Beyond judgment bias: How students' ethnicity and academic profile consistency influence teachers' tracking judgments. Social Psychology of Education, 16(4), 555-573. http://doi.org/10.1007/s11218-013-9227-5

Glock, S., Krolak-Schwerdt, S., \& Pit-ten Cate, I.M. (2015). Are school placement recommendations accurate? The effect of students' ethnicity on teachers' judgments and recognition memory. European Journal of Psychology of Education, 30(2), 169-188. http://doi. org/10.1007/s10212-014-0237-2

Good, T.L.(1987). Two decades of research on teacher expectations: Findings and future directions. Journal of Teacher Education, 38(4), 32-47. http://doi.org/10.1177/002248718703800406

Hachfeld, A., Anders, Y., Schroeder, S., Stanat, P., \& Kunter, M. (2010). Does immigration background matter? How teachers' predictions of students' performance relate to student background. International Journal of Educational Research, 49(2-3), 78-91. http://doi. org/10.1016/j.ijer.2010.09.002

Hoge, R.D. (1984). The definition and measurement of teacher expectations: problems and prospects. Canadian Journal of Education, 9(2), 213-228. http://doi.org/10.2307/1494604

Janssens, H., Verkuyten, M., \& Khan, A. (2015). Perceived social structural relations and group stereotypes: A test of the Stereotype Content Model in Malaysia. Asian Journal of Social Psychology, 18(1), 52-61. http://doi.org/10.1111/ajsp.12077

Jussim, L.J., \& Eccles, J. (1995). Are teacher expectations biased by students' gender, social class, or ethnicity? In Stereotype accuracy: Toward appreciating group differences (pp. 245-271). Washington, D.C.: American Psychological Association. http://doi.org/10.1037/10495-010 
Jussim, L.J., \& Harber, K.D. (2005). Teacher expectations and self-fulfilling prophecies: knowns and unknowns, resolved and unresolved controversies. Personality and Social Psychology Review, 9(2), 131-155. http://doi.org/10.1207/s15327957pspr0902_3

King Lewis, G.D. (2014). Teachers' expectations and reading achievement of African American middle school students. Walden University. from http://scholarworks.waldenu.edu/ dissertations/150/

Lee, T.L., \& Fiske, S.T. (2006). Not an outgroup, not yet an ingroup: Immigrants in the Stereotype Content Model. International Journal of Intercultural Relations, 30(6), 751-768. http://doi. org/10.1016/j.ijintrel.2006.06.005

Levada Center (2013). Otnoshenie k migrantam [Attitudes towards Migrants]. Moscow:Levada Analytical Center. http://www.levada.ru/2013/07/03/otnoshenie-k-migrantam/

Levada Center (2014). Natsionalizm, ksenofobiya i migratsiya [Nationalism, xenophobia and migration]. Moscow: Levada Analytical Center. http://whttp://www.levada.ru/2014/08/26/ natsionalizm-ksenofobiya-i-migratsiya/ww.levada.ru/2015/10/23/ksenofobiya-v-rossiisnizilas/

Levada Center (2015). Ksenofobiya v Rossii snizilas' [Xenophobia in Russia has fallen]. Moscow: Levada Analytical Center. http://www.levada.ru/2015/10/23/ksenofobiya-v-rossii-snizilas/

Levins, T., Bornholt, L., \& Lennon, B. (2005). Teachers' experience, attitudes, feelings and behavioural intentions towards children with special educational needs. Social Psychology of Education, 8(3), 329-343. http://doi.org/10.1007/s11218-005-3020-z

Linville, P.W., Fischer, G.W., \& Yoon, C. (1996). Perceived covariation among the features of ingroup and outgroup members: The outgroup covariation effect. Journal of Personality and Social Psychology, 70(3), 421-436. http://dx.doi.org/10.1037/0022-3514.70.3.421

Madon, S., Jussim, L., Keiper, S., Eccles, J., Smith, A., \& Palumbo, P. (1998). The accuracy and power of sex, social class, and ethnic stereotypes: A naturalistic study in person perception. Personality and Social Psychology Bulletin, 24(12), 1304-1318. http://doi. org/10.1177/01461672982412005

McKown, C., \& Weinstein, R.S. (2008). Teacher expectations, classroom context, and the achievement gap. Journal of School Psychology, 46(3), 235-261. http://doi.org/10.1016/j. jsp.2007.05.001

Page, S., \& Rosenthal, R. (1990). Sex and expectations of teachers and sex and race of students as determinants of teaching behavior and student performance. Journal of School Psychology, 28(2), 119-131. http://doi.org/10.1016/0022-4405(90)90003-P

Panova, E. (2006). "Svoi" i "Chuzhie" ucheniki: Predstavleniya peterburgskikh uchitelei ob etnicheskikh razlichiyakh i granitsakh russkosti [Students "ours" and "alien": The views of St. Petersburg teachers on ethnic diversity and the limits of Russianness]. Ab Imperio, 3, 355-388.

Parks, F.R., \& Kennedy, J.H. (2007). The impact of race, physical attractiveness, and gender on education majors' and teachers' perceptions of student competence. Journal of Black Studies, 37(6), 936-943. http://doi.org/10.1177/0021934705285955

Peterson, E.R., Rubie-Davies, C., Osborne, D., \& Sibley, C. (2016). Teachers' explicit expectations and implicit prejudiced attitudes to educational achievement: Relations with student achievement and the ethnic achievement gap. Learning and Instruction, 42, 123-140. http:// doi.org/10.1016/j.learninstruc.2016.01.010

Ready, D.D., \& Wright, D.L. (2011). Accuracy and inaccuracy in teachers' perceptions of young children's cognitive abilities: The role of child background and classroom context. American Educational Research Journal, 48(2), 335-360. http://doi.org/10.3102/0002831210374874

Regalla, M. (2013). Teacher expectations and students from low socioeconomic background: A perspective from Costa Rica. http://eric.ed.gov/?id=ED540254 
Rosenthal, R., \& Jacobson, L. (1968). Pygmalion in the classroom: Teacher expectation and pupils' intellectual development. New York: Holt, Rinehart, Winston.

Rubie-Davies, C. (2008). Teacher expectations. In 21st Century Education: A reference handbook (pp. 254-262). Thousand Oaks, CA: Sage Publications.

Rubie-Davies, C., Hattie, J., \& Hamilton, R. (2006). Expecting the best for students: Teacher expectations and academic outcomes. British Journal of Educational Psychology, 76(3), 429444. http://doi.org/10.1348/000709905X53589

Rubie-Davies, C.M., Flint, A., \& McDonald, L.G. (2012). Teacher beliefs, teacher characteristics, and school contextual factors: What are the relationships? British Journal of Educational Psychology, 82(2), 270-288. http://doi.org/10.1111/j.2044-8279.2011.02025.x

Schneider, D.J. (2004). The psychology of stereotyping. New York, London: The Guilford Press.

Sprietsma, M. (2013). Discrimination in grading: Experimental evidence from primary school teachers. Empirical Economics, 45(1), 523-538. http://doi.org/10.1007/s00181-012-0609-x

Tenenbaum, H.R., \& Ruck, M.D. (2007). Are teachers' expectations different for racial minority than for European American students? A meta-analysis. Journal of Educational Psychology, 99(2), 253-273. http://doi.org/10.1037/0022-0663.99.2.253

Timmermans, A.C., de Boer, H., \& van der Werf, M.P.C. (2016). An investigation of the relationship between teachers' expectations and teachers' perceptions of student attributes. Social Psychology of Education, 19(2), 217-240. http://doi.org/10.1007/s11218-015-9326-6

Turner, H., Rubie-Davies, C.M., \& Webber, M. (2015). Teacher expectations, ethnicity and the achievement gap. New Zealand Journal of Educational Studies, 50(1), 55-59. http://doi. org/10.1007/s40841-015-0004-1

van den Bergh, L., Denessen, E., Hornstra, L., Voeten, M., \& Holland, R. W. (2010). The implicit prejudiced attitudes of teachers: Relations to teacher expectations and the ethnic achievement gap. American Educational Research Journal, 47(2), 497-527. http://doi. org/10.3102/0002831209353594

van Ewijk, R. (2011). Same work, lower grade? Student ethnicity and teachers' subjective assessments. Economics of Education Review, 30(5), 1045-1058. http://doi.org/10.1016/j. econedurev.2011.05.008

Wigfield, A., Galper, A., Denton, K., \& Seefeldt, C. (1999). Teachers' beliefs about former Head Start and non-Head Start first-grade children's motivation, performance, and future educational prospects. Journal of Educational Psychology, 91(1), 98-104. http://doi.org/10.1016/j. learninstruc.2016.01.010

Williams, T. (1976). Teacher prophecies and the inheritance of inequality. Sociology of Education, 49 (July), 223-236.

Original manuscript received September 14, 2016

Revised manuscript accepted August 22, 2017

First published online March 30, 2018 